\title{
Biology of Parlatoria oleae C (Homoptera, Diaspididae) in the area of Cap- Djenet (Algeria)
}

\author{
Mohamed Biche and Mahdi Sellami
}

\author{
Laboratoire d'Ecologie des Vertébrés \\ Ecole Nationale Supérieure Agronomique - 16200 El-Harrach Alger \\ Email : m.biche@ensa.dz \\ ABSTRACT
}

The biology of $P$.oleae was studied over 2 years in an olive yard situated in the region of CapDjenet $\left(36^{\circ} \mathrm{E}\right.$ and $\left.3^{\circ} 7 \mathrm{~N}\right)$. It was found that the armoured scale has a cycle of two generations per year. Most often, it is the breeding females that overwinter rather than young females. Fecundity is affected by the tree phenology as well as some of the environmental factors. Increasing temperatures and thrust sap of spring, for instance, affects the time that females spend in laying eggs. It was also shown that high temperatures comprised between $30^{\circ} \mathrm{C}$ and $35^{\circ} \mathrm{C}$ affects the oviposition time as well as the number of eggs laid down. Une étude menée pendant 2 années (2001 et 2002) sur la biologie de P.oleae dans une oliveraie d'Algérie située dans la région de Cap-Djenet $\left(36^{\circ} \mathrm{E}\right.$, et $\left.3^{\circ} 7 \mathrm{~N}\right)$ à révélé que cette cochenille manifeste deux générations annuelles. L'hivernation touche essentiellement les femelles adultes fécondées, rarement les jeunes femelles. La fécondité est en étroite relation avec la phénologie de l'arbre et son environnement. L'élévation de la température et la poussée de sève printanière favorisent le potentiel de ponte. Par contre, les hautes températures comprises entre $30^{\circ} \mathrm{C}$ et $35^{\circ} \mathrm{C}$ diminuent la durée d'oviposition et le nombre d'œufs pondus.

Keywords - Homoptera, Diaspididae, Parlatoria oleae, biology, olive-tree, Algeria.

\section{INTRODUCTION}

P.oleae was described for the first time in 1880 by Colvée, observing samples of olive-tree from Valence in Spain (Balachowsky, 1953). This pest is known as affecting no less than 211 host plants (Mc Kenzie, 1952). In Algeria, P.oleae was observed for the first time in the region Constantine (east Algeria) by Eaton in 1896 and subsequently by Trabut in 1911 around Algiers. It was also observed far in south-Algeria at Laghouat by Langronier and in west-Algeria (Oran) by Frezal in 1927 (Balachowsky, 1932). Among the species belonging to the tribes of Diaspidini, Parlatorini and Aspioditini known as pests of Olea europaea (Doumandji and Biche, 1985; Biche, 1987), P.oleae is the most redoubtable pest affecting this tree and many other fruit trees in Algeria. This study aims to highlight some of the aspects of the biology of $P$.oleae in relation to the phenology of the olivetree, considered by Schvester (1956) as a primary host plant.

\section{MATERIAL AND METHODS}

This research was carried out over two consecutive years (2001-2002) in the olive-growing station of Cape-Djenet situated at $60 \mathrm{~km}$ east of Algiers. The olive grove (Chemlal variety) of 1 ha shosen as site of study consists of 9 blocks of 102 trees each, that is 918 trees in total. Samplings were carried out each week as follows : two blocks were sampled randomly every week. Five branches of $20 \mathrm{~cm}$ approximately were taken from each sampled tree, one in the centre and the others at the four cardinal points. The collected vegetable material is treated in laboratory. The deducted insect scale are classified and dissociated as individuals alive and died according to their stage of evolution. In a previous work (Biche, 1987; Biche and Bourahla, 1993), it was shown that Cape-Djenet is situated in the sub-wet bioclimatic stage with soft winter. The annual average temperature is $17^{\circ} \mathrm{C}$ and the rainfall is $600 \mathrm{~mm} / \mathrm{an}$.

\section{RESULTS}

The Olive scale insect, P.oleae presents two annual generations in Cape-Djenet: a spring generation and an autumnal generation.

The spring generation (plate 1)

The first individual counting was carried out on the $13 / 01 / 2001$. It showed a homogenous population, where adult females were estimated at $95 \%$ for only $5 \%$ of young females. At the end of February 93,24 $\%$ of the olive scale were breeding females starting to lay out their eggs. In the spring mild weather has helped to increase the number of eggs laid out. The latter are at their maximum number at the end of April; they are estimated at $89 \%$ of the population. In the other hand, the minimum number is observed by 
the end of June and the first mobile larvae is noted around mid-march 1989. Larvae number increases sharply and is at its maximum by early June. From that period on, the population of $P$.oleae has changed aspect : $52 \%$ of the individuals present are mobile larvae that will start to settle on different parts of the plants. Maximum mobile larvae numbers is registered by the end of June. Second stage starts early in April and spread till the end of July. Male line (pre-nymph and nymph), were noted for the first time in mid April and lasted till the end of July. With regard to the flight of the males, 118 empty scales were numbered at the beginning of July. Summer flight were also registered an between May and August.

\section{The autumn generation (plate 1)}

The first eggs of this generation, are laid out towards the end July and egg laying spread out until the end September. They reach their maximum number at the beginning of August (79\% of the total population numbers). Egg hatching happens progressively with the expulsion of the eggs. The structure of the population changed quickly, so that larvae numbers was at its high level by mid-August, whilst a high proportion of males and females of second stages were recorded late in September. Summer changes in population numbers leads to the appearance of new females during the last days of September. The majority of them will be fertilised and by early November, they will count for $70 \%$ of the total number of insect scale. There will be further females early in December. Indeed, the maximum rate is recorded during the winter.

Males start flying at the beginning of September and sporadic flights took place later on, to last until the end of January. The following year, the cycle resumption happened at the same period and the observations made confirmed those of the previous year.

\section{The spring egg laying (plate 2)}

In 2001, egg laying has been observed for the first time on February 28. As the temperature softens, we remarked an increase in fertility. Its highest level was registered in the last week of April with an average of $31.4 \pm 9.3$ eggs laid out per female (all the directions in the trees were merged). However the monthly average of egg laying was then higher in the East and North during April with 36.3 and 32.7 eggs laid out, respectively. As from this period, the majority of the females have laid out all their eggs, the latter have seen their numbers decrease so that the minimum average all directions merged was registered on June 24 (1,5 $\pm 1,06$ eggs per female).
In 2002, the beginning of egg laying showed a slight delay as compared to the past year. As during the previous years, the individuals being in the East and North show an early development. Thereafter, the number of eggs laid out increased regularly until midApril. Egg laying is always numerically most important in the East and North side of the trees, with 25.7 and 24.8 eggs respectively. Finally, the average of fertility for this generation was 12.78 and 14.73 eggs for 1989 and 1990, respectively (Table 2).

The highest average of monthly egg laying is recorded in April for the first generation (17.61) and during August (14.74) for the second one. It is always in the East and the North of the trees that the laying out abounds.

\section{Summer egg laying (plate 2)}

For this second generation, whatever the orientation, eggs laying out begins at the same time every year that is towards the second fortnight of July. It, then, reaches its maximum at the beginning of September with an average of 24,81 eggs per female. The orientations East and North remain privileged with 28.4 and 26.3 eggs respectively. From this period on, one attends an abrupt fall of the average number of eggs laid, until the end of September when a minimum is noted (2,06 eggs). An identical evolution is observed the following year. The maximum fertility is also observed in the end of August with 20.1 eggs per female in the East side of the trees and 19 eggs in the North. The minimum is also reached towards the end of September. Lastly, the average of egg laying for this generation is 12,10 and 12,32 eggs respectively for the year 2001 and 2002 (Table 2).

Table 1: Monthly average temperatures $\left({ }^{\circ} \mathrm{C}\right)$ in CapeDjenet and the number of effective degreedays of P.oleae

\begin{tabular}{ccc}
\hline \multirow{2}{*}{ Mounth } & \multicolumn{2}{c}{ Temperatures average } \\
\cline { 2 - 3 } & 2001 & 2002 \\
\hline January & 11,01 & 9,0 \\
February & 10,3 & 13,3 \\
Mars & 11,3 & 11,5 \\
April & 15,3 & 14,3 \\
May & 14,7 & 16.6 \\
June & 21,2 & 23,3 \\
July & 27,4 & 27,8 \\
August & 22,4 & 25,0 \\
September & 22,5 & 23,0 \\
October & 17,4 & 16,8 \\
November & 16,3 & 13,9 \\
December & 12,0 & 11,4 \\
\hline Number of degree day & 2491 & 2649 \\
Number of generation & 1,9 & 2 \\
\hline
\end{tabular}


Agric. Biol. J. N. Am., 2011, 2(1): 52-55

Table 2: Compared fruitfulness of the spring and estival period during two years of observations.

\begin{tabular}{lcccccc} 
& \multicolumn{3}{c}{2001} & \multicolumn{3}{c}{2002} \\
\cline { 2 - 7 } & Total eggs & Laying femal & Average & Total eggs & Laying femal & Average \\
\hline First generation & 10006 & 783 & 12,77 & 11195 & 760 & 14,73 \\
Second generation & 3256 & 289 & 11,26 & 3.388 & 275 & 12,32 \\
total & 13252 & 1072 & 12,36 & 14583 & 10535 & 14,09 \\
\hline
\end{tabular}

$\mathrm{F}:$ Female

\section{DISCUSSION}

P.oleae has a cycle which depends closely on the local climatic conditions. The olive scale presents two generations per year in Greece (Argyriou and Kourmadas, 1979), in Italy (Laccone, 1981) and in the United States of America (Mc Kenzie, 1952). However, in Egypt, it shows 3 annual generations (Habib and al., 1969) and can even have up to 4 generations in Palestine (Bodenheimer, 1951).

In North Africa, this scale insect is unknown. Only few works were published in relation to the bio-ecology of this species in the Maghreb, notably in Morocco (Benassy, 1967) and in Algeria (Aissaoui, 1985; Kara-Hacene, 1986; Chentir, 1990). The reason is that species became a pest on olive-tree and many other fruit trees just recently.

In Algeria, the olive scale has two annual generations. In the area of the Cap-Djenet, for instance, it has been observed a spring generation and an autumn generation. An identical cycle is also observed in the west side of Algeria (Oran) (Aissaoui, 1985) as well as in the centre (Miliana) (Chentir, 1990) on apple trees (Malus pumila) and on pear trees (Amygdalus communis) (Kara-Hacène, 1986).

The number of generations of P.oleae, observed in Cape-Djenet, is the same as the one calculated on the basis of the thermal threshold (zero of development) and the number of effective daydegrees (Bodenheimer, 1926). According to the calculations of this author the thermal threshold of $P$.oleae is $10^{\circ} \mathrm{C}$ and the number of effective daydegrees required for a generation is 1300 days. This confirms the results shown in this study (table 1) that are 2491 and 2649 degree-days effective which is required for the 2 generations found in 2001 and 2002. Similar results were noted in Greece (Argyriou and Kourmadas, 1973) and in Israel (Applebaum and Rosen, 1964).

With regard to the mobile larvae, it is important to note the spread out between the two generations.
This phenomenon is a result of the wintering females egg lay out which lasts up to four months. The new added eggs will increase the number of the individuals in the first generation. The first eggs laid out will become the mobile larvae observed at the beginning of the second generation even before the completion of the lay out from females of the wintering generation. It is important to note that egg hatching which is weak in spring will increase from mid-July till the end of October during the second generation.

The first fixed stages appear at the same time with the mobile larvae, that is for the first generation towards the end of March. Their presence is prolonged until the beginning of July for the latter and the beginning of August for the second one. It will last till the end of November. Larvae of the second stage (females and males) are observed from the end of March till the end of July for the first generation. Concerning the second generation, the presence of larvae was observed from the last decade of August till the end of November. The pre-nymphs and the nymphs are present during the first generation from the very beginning of May. Their number keeps varying until the end of July. They appear at the end of the season as from the second decade of September. Identical observations were made in 1990.

Female of $P$.oleae spend the winter as fertilised adult and rarely in immature condition. The latter will be fertilised by males of the spring flight. The hibernation can affect females larvae of the second stage but in very low number (Argyriou and Kourmadas, 1979; Kara-Hacene, 1986 and Chentir, 1990).

During the winter period, the population of P.oleae is mainly represented by adult females. In this season, the olive-tree is in a state of vegetative rest which lasts from November till February. During all this time, the monthly average temperature does not exceed $11^{\circ} \mathrm{C}$. Late in March, there the first signs of the spring start to show up. The final growths and the blossoming of the auxiliary buds are the results of the 
increase in temperatures and the push of spring sap. This reaction of the olive-tree coincides with the egglaying of P.oleae. There is a correlation between the two phenomena. Moreover, it is worth noticing that for temperatures higher than $10^{\circ} \mathrm{C}$ (zero of development), egg-laying can happen if the plant host restart its development. This phenomenon is noticed in Molos in Greece (Argyriou and Kourmadas, 1979). If it does not happen the number of eggs laid out is almost no one. It is probable that this is the result of a simultaneous action of the two associated factors that supporting and controlling the fertility of this insect scale (the spring period).

The duration of egg-laying is related to the local climatic conditions and with the host plant cycle of development. In Algeria, the duration of spring egglaying is spread out than that of the summer period. It is known that this phenomenon is due to the abundance of the nutritive reserves stored by the females for the winter period. It, also, contributes directly to the process of the ovogenesis and the multiplication of the ovocyts.

Lastly, according to the results presented here, it arises that the high summer temperatures ranging between $86^{\circ} \mathrm{F}$ and $95^{\circ} \mathrm{C}$ affects the period of egglaying. Indeed, Habib and al. (1969) affirm that for P.oleae, the duration of the period which arrives ahead the egg-laying and the process itself decreases with the rise in temperatures. Bourijate and Bonafonte (1982), consider that a differed mating causes a decrease in the period of egg-laying with an increase in egg-laying for the species with unchanged fertility such as Aonidiella aurantii and Lepidosaphes beckii.

\section{REFERENCES}

Aissaoui, K., 1985 - Etude biologique de Parlatoria oleae Colvée (Hom., Diaspididae) dans un verger de pommiers à Oued Rhiou dans la région de Rélizane. Mém. Ing. agro., Inst .Nat. Agron., El-Harrach, pp. 45.

Applebaum, S.W. \& Rosen, D., 1964 - Ecological studies on the olive scale Parlatoria oleae Colvée en Israël. J. Econ. Entomol., USA., (57), $n^{\circ} 6$, pp. 847-850.

Argyriou, L.C. \& Kourmadas, A.L., 1979 - Notes on biology and the natural enemies of the olive scale Parlatoria oleae (Colvée) on olive trees in central Greece. Med. Fac. Landbrouwn. Rijks. Univ., Gent, 44 (1) : 39-47.
Balachowsky, A.S., 1932 - Etude biologique des Coccidés du bassin méditerranéen. Ed. P.Lechevalier et fils, Paris, tome 15, pp. 235

Balachowsky, A.S., 1953 - Les cochenilles de France, d'Europe, du Nord de l'Afrique et du bassin méditerranéen. Ed. Hermann et Cie, Coll. "Actua. Sci. et Ind. ", $n^{\circ} 874$, tome 3, pp. 114

Benassy, C., 1967 - Note sur Parlatoria oleae Colvée au Maroc Ann. Soc. Ent. Fr., (N.S.), 3 (1) : 165-171.

Biche, M., 1987 - Bioécologie de Parlatoria oleae Colvée (Hom. Diaspididae) ravageur de l'olivier, Olea europaea L. dans la région du Cap-Djenet (Algérie) et étude biologique de son parasite externe Aphytis maculicornis Masi (Hym. Aphelinidae). Mém. Dip. Univ. Rech., Univ. Nice, pp.119

Biche, M. \& Bourahla, M., 1993 - Observations sur la bioécologie de Lepidosaphes destefanii Leonardi ravageur de l'olivier dans la région du Cap-Djenet (Homoptera, Diaspididae). Bull. Soc. Entomol. Fr., 98 (1), : 23-27.

Bodenheimer, H.S., 1951 - Citrus entomology in the middle East. Uitgeverij Dr W.Junk, S'Gravenhag, pp. 663

Bourijate, M. \& Bonafonte, P., 1982 - Influence de l'accouplement différé sur la fécondité, le sex-ratio, l'oviposition, la formation du bouclier et le comportement chez quatre espèces de cochenilles diaspines (Hom., Diaspididae). Ann. Soc. Entomol. Fr., (N.S.), 18 (3) : 303-315

Chentir, M., 1990 - Bioécologie de Parlatoria oleae C. (Hom. Diaspididae) sur pommier dans la région de Miliana et étude biologique de son parasite externe Aphytis maculicornis M. (Hym Aphelinidae). Mém. Ing. agro. Inst.Nat.Enseig.Sup., (Algérie) pp. 58

Doumandji, S \& Biche, M., 1985 - Les cochenilles diaspines de l'olivier Olea europaea L., en Algérie. $1^{\text {er }}$ Journ. Etud. Biol. Ennem. Cult. Dég. et Moy. Lutte, Inst.Nat.Agro., El-Harrach, (Algerie), pp. 18

Kara Hacène, T. 1986 - Etude de la bioécologie des cochenilles Parlatoria oleae (Colvée), Quadraspidiotus lenticularis (Lind.) et Quadraspidiotus pyri (Licht.) à Beni Allel dans la région de Miliana. Mém.Ing. Agro., Inst .Nat. Agron., (Algérie), pp. 84

Laccone, G., 1981 - Parlatoria oleae Colvée (Hom., Diaspididae) su olivo in puglia cenni de biologia e prove di lotta estratto de " Informatore fitipatologia ", $\mathrm{n}^{\circ} 112: 73-76$

Mc Kenzie, H.L., 1952 - Distribution and biological notes on the olive scale, Parlatoria oleae (Colvée) in California. Bull. Dept. Agric. California, 41, $n^{\circ} 3$, : 127138. 